\title{
Supplementation with corn oil and palm kernel oil to grazing cows: ruminal fermentation, milk yield, and fatty acid profile
}

\author{
Jair Esteban Parales Girón'1, Martha Lucía Pabón Restrepo¹, Juan Evangelista Carulla \\ Fornaguera $^{1}$
}

${ }^{1}$ Universidad Nacional de Colombia, Bogotá, Colombia.

\begin{abstract}
The effect of supplementation with corn oil (CO) and its mixture with palm kernel oil (CO:PKO 75:25) to grazing cows on ruminal fermentation, milk yield, and its fatty acid (FA) profile was evaluated. The treatments were: one control treatment (C) without oil and two treatments with $720 \mathrm{~g} \mathrm{~d}^{-1} / \mathrm{cow}$ of CO or CO:PKO (ether extract: $22.7 \mathrm{~g} \mathrm{~kg}^{-1}$ for control treatment, $66 \mathrm{~g} \mathrm{~kg}^{-1}$ for $\mathrm{CO}$, and $65 \mathrm{~g} \mathrm{~kg}^{-1}$ for CO:PKO). Six multiparous Holstein cows (6.3 $\pm 1.8 \mathrm{yr}, 597 \pm 11.5 \mathrm{~kg}$ body weight $(\mathrm{BW}), 160 \pm 29 \mathrm{~d}$ in milk; mean \pm standard deviation) were assigned to a double $3 \times 3 \times 3$ Latin square design. Cows grazed (3 kg DM/100 kg BW) a Cenchrus clandestinus (previously Pennisetum clandestinum) pasture and were supplemented with $0.9 \mathrm{~kg} \mathrm{~d}^{-1} \mathrm{DM}$ corn silage, $4.2 \mathrm{~kg} \mathrm{~d}^{-1} \mathrm{DM}$ concentrate, and $9 \mathrm{~g} \mathrm{Cr}_{2} \mathrm{O}_{3}$. The mixture of concentrate and oils was offered twice a day. The addition of oils increased milk yield $\left(\mathrm{kg} \mathrm{d}^{-1}\right)$ (C: 21.4, CO: 23.6, CO:PKO: 23.9) and milk fat concentration ( $\left.\mathrm{g} \mathrm{kg} \mathrm{milk}{ }^{-1}\right)(\mathrm{C}: 31.5$, CO: 34.0, CO:PKO: 34.0). Compared with control, conjugated linoleic acid $\left(18: 2_{\mathrm{c} 9 \mathrm{t} 11}\right.$ CLA) proportion $\left(\mathrm{g} 100 \mathrm{~g}^{-1} \mathrm{FA}\right)$ in milk fat was higher for oil treatments (C: 0.68, CO: 1.56, CO:PKO: 1.01). Voluntary intake and digestibility were not different among treatments. The molar ratio of acetate, propionate, and butyrate was not different among treatments, but the molar concentration of volatile fatty acids (VFA) was lower for $\mathrm{CO}$ and $\mathrm{CO}: \mathrm{PKO}$, resulting in a lower estimated methane $\left(\mathrm{CH}_{4}\right)$ production $(\mathrm{mL} / 100 \mathrm{~mol} \mathrm{VFA})$ for $\mathrm{CO}$ and $\mathrm{CO}$ : $\mathrm{PKO}$ treatments. Supplementing CO and CO:PKO to grazing dairy cows increases milk yield without affecting voluntary intake or diet digestibility. The proportion of conjugated linoleic acid increases more for CO than for CO:PKO.
\end{abstract}

Key Words: conjugated linoleic acid, methane, milk composition

\section{Introduction}

Addition of lipids to diets of grazing dairy cows may increase milk yield and change milk composition and its fatty acid (FA) profile (Khanal and Olson, 2004; Schröeder et al., 2004). Response depends on dose and fatty acid profile. High doses $\left(>50 \mathrm{~g} \mathrm{~kg}^{-1}\right)$ may depress intake and compromise rumen fermentation (Zinn et al., 2000; Plascencia et al., 2003; Montgomery et al., 2008). Supplementing saturated lipids increases milk fat, while unsaturated rich FA lipids decrease it (Schröeder et al., 2004). High levels of long chain polyunsaturated FA lipids increase trans-vaccenic $\left(18: 1_{\text {t11 }}\right.$; TVA) and conjugated linoleic acids $\left(18: 2_{\mathrm{c} 9 \mathrm{t} 11} ; \mathrm{CLA}\right)$ in milk, which are considered functional for their positive effects on human health (Druart et al., 2014; Lim et al., 2014; Yang et al., 2015). Ruminal biohydrogenation of oils rich in linoleic acid $\left(18: 2_{\mathrm{c} 9 \mathrm{c} 12}\right)$

Received January 26, 2016 and accepted July 16, 2016

Corresponding author: jeparalesg@unal.edu.co

http://dx.doi.org/10.1590/S1806-92902016001100008

Copyright (c) 2016 Sociedade Brasileira de Zootecnia. This is an Open Access article distributed under the terms of the Creative Commons Attribution License (http://creativecommons.org/licenses/by/4.0/), which permits unrestricted use, distribution, and reproduction in any medium, provided the original work is properly cited. such as corn oil produces higher concentrations of TVA than oils rich in linolenic acid $\left(18: 3_{\mathrm{c} 9 \mathrm{cl} 2 \mathrm{c15}}\right)$ in vitro and in vivo (Matsushita et al., 2007; Castillo et al., 2012). In vivo, higher ruminal proportions of TVA have been associated with higher CLA and TVA milk proportions (Harvatine and Bauman, 2006).

Supplementing fats and oils to ruminants reduces methane $\left(\mathrm{CH}_{4}\right)$ emission (Martin et al., 2010; Patra and $\mathrm{Yu}$, 2013) and their antimethanogenic effect seems to depend on their FA profile (Beauchemin et al., 2008; Patra, 2014). Oils rich in saturated medium chain FA (coconut and palm kernel oil) seem to exert a more powerful antimethanogenic effect than oils rich in long chain unsaturated FA (Machmüller et al., 2003; Beauchemin et al., 2008; Martin et al., 2010). However, supplementing oils rich in medium chain saturated FA (lauric 12:0, myristic 14:0, and palmitic 16:0) to dairy cows increases their concentration in milk (Storry et al., 1971; Hermansen, 1995; Hristov et al., 2009). Intake of fats rich in these acids increases blood cholesterol (Grundy, 1994; Mensink et al., 2003), risk of heart stroke (Kromhout et al., 1995), and atherosclerotic disorders (Nicolosi et al., 1997).

We hypothesize that supplementation with a mixture of oils rich in 18:2 $2_{\mathrm{c} 9 \mathrm{c} 2}$ (corn) and 12:0 (palm kernel oil) to 
grazing dairy cows may enhance the effect of each FA in $\mathrm{CH}_{4}$ emissions, when compared with cows supplemented with $18: 2_{\mathrm{c} 9 \mathrm{c} 12}$ (corn oil) or a diet without oils. Additionally, supplementation with the mixture of oils could produce a similar milk yield and milk fatty acid profile than cows supplemented with corn oil. The objective of this experiment was to determine the effect of including corn oil (CO) and its mixture with palm kernel oil (CO:PKO 75:25) on ruminal fermentation, milk yield, and its FA composition in grazing cows.

\section{Material and Methods}

All the experimental procedures were approved by the Bioethics Committee of Facultad de Medicina Veterinaria $y$ de Zootecnia (School of Veterinary Medicine and Animal Production; Act 004 of 2012). The experiment was conducted in Mosquera, Cundinamarca, Colombia (4'40'89" N latitude and $74^{\circ} 13^{\prime} 13^{\prime \prime} \mathrm{W}$ longitude, at an altitude of $2540 \mathrm{~m}$ ) between December 2013 and February 2014. The average temperature is $13{ }^{\circ} \mathrm{C}$ (with a 0 to $20^{\circ} \mathrm{C}$ range); relative humidity ranges between $80-85 \%$, and precipitation is $900 \mathrm{~mm} \mathrm{yr}^{-1}$, with two rainy seasons (April to May and September to November). The experiment lasted 63 days, divided into three periods of 21 days each (14 days of adaptation to treatments and seven days for sampling). Cows grazed a Kikuyu (Cenchrus clandestinus) pasture and were supplemented with $3 \mathrm{~kg} \mathrm{~d}^{-1}$ corn silage (30 $\mathrm{g} \mathrm{kg}^{-1} \mathrm{DM}$ ) and $4.2 \mathrm{~kg} \mathrm{~d}^{-1}$ concentrate (Tables 1 and 2). The treatments were: control diet C: Kikuyu, corn silage and concentrate, $\mathrm{CO}$ : control diet plus $720 \mathrm{~g} \mathrm{~d}^{-1}$ of pure corn oil supplementation, and PKO: control diet plus $720 \mathrm{~g} \mathrm{~d}^{-1}$ of a mixture of corn oil and palm kernel oil at a 75:25 ratio (Table 3).

Six Holstein cows $(6.3 \pm 1.8$ years, $597 \pm 11.5 \mathrm{~kg}$ weight, $160 \pm 29$ days in lactation, and $22.1 \pm 2.3 \mathrm{~kg} \mathrm{~d}^{-1}$ milk yield; mean \pm standard deviation) were randomly assigned to a double Latin square (three periods, three treatments, three cows, two squares). The cows were milked twice a day $(5.00 \mathrm{~h}$ and $14.00 \mathrm{~h})$ using mechanical milking and strip grazed a kikuyu pasture fenced by an electric cord that was moved twice a day (morning and afternoon). Forage allowance was $3 \mathrm{~kg}$ of dry matter (DM) per $100 \mathrm{~kg}$ body weight (BW). At each milking (morning and afternoon), each cow received $60 \mathrm{~g}$ mineralized salt, $1.5 \mathrm{~kg}$ DM of corn silage, $2.1 \mathrm{~kg}$ DM concentrate, and $4.5 \mathrm{~g}$ chromium oxide. Each cow in the treatment with oils was supplemented twice a day with $360 \mathrm{~g}$ (estimating daily dose of $40 \mathrm{~g} \mathrm{~kg}^{-1}$ total diet with an intake of $18 \mathrm{~kg} \mathrm{DM}$ ) of corn oil or a mixture of corn oil and palm kernel oil (75:25).
To calculate forage biomass, samples of three pasture heights (low, medium, and high) were individually harvested using hand shears and a square of $0.5 \mathrm{~m}^{2}$ by triplicate. The proportion of each height within the pasture was assessed by grading the pasture visually in at least 36 points. The points were evenly distributed within the whole pasture by dividing it in four areas (eight point each). Samples were weighted and dried to determine average forage production for each pasture height. Then, the estimated forage production ( $\mathrm{kg} \mathrm{DM} / \mathrm{ha}$ ) per each height was multiplied by its proportion in the pasture. A geo-positioning equipment GPSMAP ${ }^{\circledR}$ 76CSX (Garmin Ltda., Kansas, USA) was used to determine the daily area required in each strip.

For each one of the three experimental periods, milk yield was recorded at each milking time (morning and afternoon) between days 15 and 21. Two individual milk samples $(100 \mathrm{~mL})$ from each milking were collected on days 15,18 , and 21 in each experimental period. These samples were mixed to obtain one sample per cow on each sampling day and were used for milk FA analysis. On day 21, an additional sample per animal (morning and afternoon) was obtained and divided into two aliquots of $100 \mathrm{~mL}$ each; one aliquot was preserved by adding $3 \mathrm{~mL}$ of potassium dichromate at $6 \mathrm{~g} \mathrm{~L}^{-1}$ and kept at $-20{ }^{\circ} \mathrm{C}$. The other aliquot was sent fresh to the laboratory to determine protein, fat, and total solids by ultrasound (Milk analyzer, Lactan 1-4) (Priev and Barenholz, 2010).

Forage, silage, and supplements: on days 14, 16, 18, and 20 in each period, a sample of kikuyu was collected (500 g approximately) using the "hand-plucking" methodology described by Cook (1964). Daily forage samples were mixed to obtain a unique sample for each day, dried at $60{ }^{\circ} \mathrm{C}$ for $48 \mathrm{~h}$ and ground in a Romer ${ }^{\circledR}$ mill with a $2 \mathrm{~mm}$ sieve. A sample from each supplement was obtained on day 13 in each period (500 g approx.) and a corn silage sample was obtained on days $14,16,18$, and 20 . These samples were processed in the same way as forage.

Ruminal fluid $(250 \mathrm{~mL})$ was collected at $16.30 \mathrm{~h}$ on day 21 of each period using an oro-ruminal probe (Haumptner ${ }^{\circledR}$ ) discarding the first $200 \mathrm{~mL}$ for possible contamination with saliva and the remaining volume was filtered using two layers of cheese cloth. An aliquot was used to measure $\mathrm{pH}$ using a potentiometer (Beckman). Another sample $(50 \mathrm{~mL})$ was acidified with hydrochloric acid $6 \mathrm{~N}(2.5 \mathrm{~mL})$ and frozen at $-20{ }^{\circ} \mathrm{C}$ for later analysis (Lopez et al., 2016).

A daily sample (300 g approximately) of feces was collected between days 15 and 21 of each period by anus stimulation, avoiding urine contamination after the morning milking. Feces were dried at $60{ }^{\circ} \mathrm{C}$ for $48 \mathrm{~h}$, ground in 
a Romer $^{\circledR}$ mill with a $2 \mathrm{~mm}$ sieve and mixed to obtain a sample per period for each cow.

Milk fat was extracted with the method described by Hurley et al. (1987) and Díaz-González et al. (2002). One hundred milliliters of milk were centrifuged (15 min at $3000 \mathrm{rpm}$ ) and the aqueous fraction was removed. The creamy supernatant was mixed with $15 \mathrm{~mL}$ of detergent solution (50 g of sodium hexametaphosphate and 24 of Triton X-100 mL dissolved in 11 of water), stirred, and placed in a water bath $\left(10 \mathrm{~min}\right.$ at $\left.90{ }^{\circ} \mathrm{C}\right)$. The fat from the surface layer was removed using a Pasteur pipette, stored at $-20{ }^{\circ} \mathrm{C}$, and solubilized in dichloromethane (1:9). The methyl esters were formed according to the method of McCreary, et al. (1978) and quantified by gas chromatography (GC).

Forage, silage, and supplement FA were extracted according to Garcés and Mancha (1993) adapted by Yamasaki et al. (1999). For FA methylation, $50 \mathrm{mg}$ of dry forage, silage, or supplement were weighed and $2150 \mu \mathrm{L}$ of absolute methanol, $990 \mu \mathrm{L}$ of toluene, $1000 \mu \mathrm{L}$ of $\mathrm{N}$, $\mathrm{N}$-dimethylformamide, $66 \mu \mathrm{L}$ of sulfuric acid $99.9 \%$, and $2 \mathrm{~mL}$ of $\mathrm{n}$-hexane were added. The mixture was placed in a water bath $\left(2 \mathrm{~h}\right.$ at $\left.80{ }^{\circ} \mathrm{C}\right)$ and left for 5 to $10 \mathrm{~min}$. The supernatant was evaporated under nitrogen and the dried sample was reconstituted with $300 \mu \mathrm{L}$ of dichloromethane for further analysis by GC.

Methylated FA of forage, silage, supplements, and milk were quantified by GC using a Shimadzu ${ }^{\circledR}$ GC-2014 gas chromatograph with FID detector and a $100 \mathrm{~m} \times$ $0.25 \mathrm{~mm} \times 0.2 \mu \mathrm{m}$ Rt $2560\left(\right.$ Restek $\left.^{\circledR}\right)$ capillary column.

Table 1 - Chemical composition of forages and concentrate

\begin{tabular}{lccc}
\hline & Kikuyu & Corn silage & Concentrate \\
\hline & \multicolumn{3}{c}{$\mathrm{g} \mathrm{kg}^{-1} \mathrm{DM}$} \\
Crude protein & 161.7 & 72.7 & 202.3 \\
Neutral detergent fiber & 512.2 & 568.1 & 161.6 \\
Acid detergent fiber & 223.0 & 309.3 & 46.9 \\
Non-structural carbohydrate & 174.3 & 263.0 & 557.7 \\
Ether extract & 33.1 & 22.6 & 9.1 \\
Ash & 118.7 & 73.7 & 69.3 \\
Net energy of lactation & 1.88 & 1.98 & 2.02 \\
$($ Mcal/kg of DM) & & &
\end{tabular}

DM - dry matter.

${ }^{1}$ Net energy of lactation at $1 \mathrm{x}$ maintenance intake (NRC, 2001).

Table 2 - Concentrate composition

\begin{tabular}{lc}
\hline Ingredient & $\mathrm{g} \mathrm{kg}^{-1}$ as fed \\
\hline Soybean meal & 381.0 \\
Ground corn & 266.0 \\
Molasses & 100.0 \\
Cassava meal & 190.0 \\
Wheat middlings & 23.0 \\
Calcium carbonate & 39.6 \\
Mineral premix & 0.4
\end{tabular}

The chromatographic conditions were: $260{ }^{\circ} \mathrm{C}$ and $270{ }^{\circ} \mathrm{C}$ temperature of injection and detection port, respectively; the program was fixed at an initial temperature of $140{ }^{\circ} \mathrm{C}$ for 5 min with a further increase of $4{ }^{\circ} \mathrm{C}$ per minute up to $190{ }^{\circ} \mathrm{C}$ for a total time of $60 \mathrm{~min}$. Helium was used as carrier gas, with 40.4 psi pressure and a split ratio of $1: 100$. The injected volume was $1 \mu \mathrm{L}$.

To determine the proportion of volatile fatty acids (VFA), $800 \mu \mathrm{L}$ of ruminal fluid and $500 \mu \mathrm{L}$ of internal solution (100 $\mathrm{g} \mathrm{L}^{-1}$ of metaphosphoric acid and $0.6 \mathrm{~g} \mathrm{~L}^{-1}$ of crotonic acid as internal standard, $4{ }^{\circ} \mathrm{C}$ ) were mixed, and then centrifuged three times at $13000 \mathrm{rpm}$ per minute to remove impurities. The VFA (acetate, propionate, butyrate, valerate, and isovalerate) were quantified by GC with a Shimadzu ${ }^{\circledR}$ GC-2014 gas chromatograph with a FID detector and a polyethylene glycol capillary column of $25 \mathrm{~m} \times 0.32 \mathrm{~mm} \times 0.5 \mu \mathrm{m}$ Agilent ${ }^{\circledR}$ HP-FFAP (Agilent Technologies Inc., Santa Clara, CA, USA). The chromatographic conditions were: $260{ }^{\circ} \mathrm{C}$ at injection port, $280{ }^{\circ} \mathrm{C}$ at detection port, helium as a carrier with a flow of $42 \mathrm{~cm} / \mathrm{s}$ and a split gas ratio of 1:50 and $10 \mathrm{~min}$ for the program. The injected volume was $1 \mu \mathrm{L}$.

Forage, silage, and supplements were analyzed for DM, fat, ash, crude protein (AOAC, 2010), neutral detergent fiber (NDF), acid detergent fiber (ADF) (Van Soest et al., 1991), indigestible acid detergent fiber (iADF) (Sunvold and Cochran, 1991), and FA profile using GC (Garcés and Mancha, 1993; Yamasaki et al., 1999). Non-starch carbohydrates (NSC) and net energy for lactation $\left(\mathrm{NE}_{\mathrm{L}}\right)$ were determined according to NRC (2001).

Table 3 - Fatty acid profile of forages, concentrate, corn oil, and corn oil and palm kernel oil mixture $(75: 25)\left(\mathrm{g}_{100 \mathrm{~g}^{-1}}\right.$ of fatty acids)

\begin{tabular}{lccccc}
\hline Fatty acid & Kikuyu & $\begin{array}{c}\text { Corn } \\
\text { silage }\end{array}$ & Concentrate & $\begin{array}{c}\text { Corn } \\
\text { oil }\end{array}$ & $\begin{array}{c}\text { Corn oil }+ \\
\text { palm kernel } \\
\text { oil }\end{array}$ \\
\hline $8: 0$ & 1.01 & 5.85 & 0.52 & - & - \\
$10: 0$ & 2.26 & 1.65 & 1.64 & - & - \\
$12: 0$ & - & - & - & - & 8.40 \\
$14: 0$ & - & - & 1.05 & 0.13 & 2.91 \\
$14: 1_{\mathrm{c} 9}$ & - & 3.06 & - & 0.03 & 0.03 \\
$16: 0$ & 28.91 & 23.04 & 14.91 & 11.80 & 10.67 \\
$16: 1_{\mathrm{c} 9}$ & 13.97 & - & 10.60 & 0.03 & 0.05 \\
$16: 1^{13}$ & - & - & - & 0.21 & 0.26 \\
$18: 0$ & - & - & - & 5.18 & 4.87 \\
$18: 1_{\mathrm{c} 9}$ & - & 13.75 & 15.60 & 20.66 & 19.65 \\
$18: 2_{\mathrm{t} 9 \mathrm{t} 12}$ & - & - & - & 0.41 & 0.50 \\
$18: 2_{\mathrm{c} 9 \mathrm{c} 12}$ & 13.41 & 27.50 & 40.45 & 53.99 & 41.91 \\
$18: 3_{\mathrm{c} 6 \mathrm{c} 9 \mathrm{c} 12}$ & - & - & - & 0.26 & 0.15 \\
$18: 3_{\mathrm{c} 9 \mathrm{c} 12 \mathrm{c} 15}$ & 34.06 & 17.16 & 12.36 & 5.51 & 3.61 \\
Others & 6.37 & 7.99 & 2.86 & 1.80 & 6.99 \\
\hline
\end{tabular}


Milk protein, fat, and total solids were determined by ultrasound (Priev and Barenholz, 2010).

$\mathrm{pH}$ was determined in the ruminal fluid using a Beckman $^{\circledR}$ potentiometer.

In the feces, iADF was determined using the Sunvold and Cochran (1991) method and chromium concentration by X-ray fluorescence spectroscopy (S2 PICOFOX ${ }^{\circledR}$ BRUKER $^{\circledR}$ ).

Concentration of $\mathrm{CH}_{4}$ was calculated according to

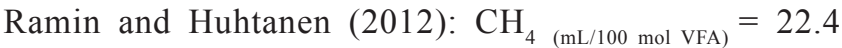
$\times\left(0.5 \times \mathrm{C}_{2}-0.25 \times \mathrm{C}_{3}+0.50 \times \mathrm{C}_{4}-0.25 \times \mathrm{VA}\right)$, in which $\mathrm{C}_{2}=$ propionic acid proportion; $\mathrm{C}_{3}=$ acetic acid proportion; $\mathrm{C}_{4}=$ butiric acid proportion; and $\mathrm{VA}=$ valeric acid proportion.

Energy-corrected milk (ECM) was calculated according to Peterson et al. (2012): ECM $\left(\mathrm{kg} \mathrm{d}^{-1}\right)=(0.327 \times$ milk yield $\left.\mathrm{kg} \mathrm{d}^{-1}\right)+\left(12.87 \times\right.$ fat $\left.\mathrm{kg} \mathrm{d}^{-1}\right)+\left(7.65 \times\right.$ protein $\left.\mathrm{kg} \mathrm{d}^{-1}\right)$.

For forage intake, chromium oxide $\left(\mathrm{Cr}_{2} \mathrm{O}_{3}\right)$ was used as external marker to determine feces production (Holden et al., 1994) and iADF was used as an internal marker (Sunvold and Cochran, 1991). Feces production $\left(\mathrm{kg} \mathrm{d}^{-1}\right)$ was determined according to Holden et al. (1994): $\mathrm{FP}=\mathrm{EMD} \times \mathrm{R} \times\left[\mathrm{EM}_{\mathrm{F}}\right]^{-1} \times 1,000^{-1}$, in which $\mathrm{FP}=$ feces production $\left(\mathrm{kg} \mathrm{d}^{-1}\right)$; EMD $=$ external marker dose $(\mathrm{g}$ of $\left.\mathrm{Cr} \mathrm{d}^{-1}\right) ; \mathrm{R}=$ recovery rate; and $\left[\mathrm{EM}_{\mathrm{F}}\right]=$ fecal external marker concentration ( $\mathrm{g}$ of $\mathrm{Cr} \mathrm{g}^{-1}$ of DM).

Forage intake was calculated according to Aguilar et al. (2009) $: \mathrm{FoI}=\left(\mathrm{FP} \times[\mathrm{iADF}]_{\mathrm{F}}-\mathrm{SI} \times[\mathrm{iADF}]_{\mathrm{S}}\right) \times[\mathrm{iADF}]_{\mathrm{Fo}}{ }^{-1}$, in which $\mathrm{FoI}=$ forage intake $\left(\mathrm{kg}\right.$ of $\left.\mathrm{DM} \mathrm{d} \mathrm{d}^{-1}\right)$; $\mathrm{FP}=$ feces production $\left(\mathrm{kg}\right.$ of $\left.\mathrm{DM} \mathrm{d} \mathrm{d}^{-1}\right)$; $[\mathrm{iADF}]_{\mathrm{F}},[\mathrm{iADF}]_{\mathrm{S}}$, and $[\mathrm{iADF}]_{\mathrm{Fo}}$ $=$ feces, supplement, and forage $\mathrm{iADF}$ concentrations, respectively ( $\mathrm{g}$ of $\mathrm{iADF} \mathrm{g}^{-1}$ of $\mathrm{DM}$ ); and $\mathrm{SI}=$ supplement intake ( $\mathrm{kg}$ of $\left.\mathrm{DM} \mathrm{d}^{-1}\right)$.

Atherogenicity index (AI) was calculated according to Ulbricht and Southgate (1991): $\mathrm{AI}=\left(\mathrm{C}_{12}+4 \mathrm{C}_{14}+\mathrm{C}_{16}\right) \times$ $\mathrm{UFA}^{-1}$, in which $\mathrm{C}_{12}=$ lauric acid g $100 \mathrm{~g}^{-1} ; \mathrm{C}_{14}=$ myristic acid $\mathrm{g} 100 \mathrm{~g}^{-1} ; \mathrm{C}_{16}=$ palmitic acid $\mathrm{g} 100 \mathrm{~g}^{-1}$; and UFA = unsaturated FA g $100 \mathrm{~g}^{-1}$.

Thrombogenicity index (TI) was calculated according to Ulbricht and Southgate (1991): $\mathrm{TI}=\left(\mathrm{C}_{14}+\mathrm{C}_{16}+\mathrm{C}_{18}\right)$ $\times\left[0.5_{\text {MUFA }}+0.5 \omega 6+3 \omega 3+(\omega 3 / \omega 6)\right]^{-1}$, in which $\mathrm{C}_{14}=$ myristic acid g $100 \mathrm{~g}^{-1} \mathrm{FA} ; \mathrm{C}_{16}=\mathrm{g} 100 \mathrm{~g}^{-1}$ of palmitic acid; $\mathrm{C}_{18}=$ stearic acid g $100 \mathrm{~g}^{-1} ; \mathrm{MUFA}=$ monounsaturated FA g $100 \mathrm{~g}^{-1} ; \omega 3=$ omega 3 FA g $100 \mathrm{~g}^{-1}$; and $\omega 6=$ omega 6 FA $\mathrm{g} 100 \mathrm{~g}^{-1}$.

Data were subjected to analysis of variance for a double $3 \times 3 \times 3$ Latin square design with a residual effect estimation using PROC MIXED function of SAS (Statistical Analysis System, version 9.0), according to the following model:

$$
Y i j(k) l=\mu+a l+b(a) i l+c(a) j l+\beta(k)+e i j(k) l,
$$

in which: $Y i j(k) l=$ dependent variable; $\mu=$ overall mean; $a l=$ random effect of square $l ; b(a) i l=$ random effect of period $i$ within square $l ; c(a) j l=$ random effect of cow $j$ within square $l ; \beta(k)=$ fixed effect of treatment $k$ discriminated in direct and carryover effect; and $e i j(k) l=$ random error with mean 0 and variance $\sigma^{2}$. All random effects were considered $\sim \mathrm{N}\left(0, \sigma^{2} \mathrm{e}\right)$. Significant differences were considered at $\mathrm{P}<0.05$ for main effects. For multiple comparisons among treatment means, the Turkey-Kramer test was used.

\section{Results}

Forage DM intake and total intake were not affected by treatments. Silage and concentrate intake were consistent among the three periods and no rejections occurred (Table 4).

Digestibility of DM, organic matter (OM), NDF, ADF, and molar proportions of VFA were not different among treatments. The addition of oils decreased the concentration of VFA $(\mathrm{P}<0.0001)$, increased ruminal $\mathrm{pH}(\mathrm{P}=0.0024)$, and did not affect total $\mathrm{CH}_{4}$ production, but decreased the amount of $\mathrm{CH}_{4}$ produced per mol of total VFA for these treatments $(\mathrm{P}<0.0001)$ (Table 5).

Daily milk yield and energy-corrected milk (ECM) were lower for treatment $\mathrm{C}$ than for the treatments with oils $(\mathrm{P}=0.0046$ and $\mathrm{P}=0.0021$, respectively). Compared with $\mathrm{C}$, the concentration of total solids and milk fat was higher for those cows supplemented with oils $(\mathrm{P}=0.0320$ and $\mathrm{P}=0.0184$ respectively). Milk protein concentration was not different among the three treatments. Compared with $\mathrm{C}$, the daily yields of total solids and fat were higher for the cows supplemented with oils $(\mathrm{P}=0.0320$ and $\mathrm{P}=0.0184$, respectively) (Table 6).

Lower levels of 8:0, 10:0, 11:0, and 18:2 ${ }_{10 \mathrm{c} 12}$ FA were found in milk from cows in the oil treatments than $\mathrm{C}$ treatment $(\mathrm{P}<0.0001, \mathrm{P}=0.0061, \mathrm{P}=0.0476$, and $\mathrm{P}=0.0155$ respectively) (Table 7 ).

Table 4 - Intake $\left(\mathrm{kg} \mathrm{d}^{-1}\right)$ by grazing cows supplemented with $720 \mathrm{~g} \mathrm{~d}^{-1}$ of corn oil or its mixture with palm kernel oil (75:25) or unsupplemented (control)

\begin{tabular}{lccccc}
\hline & \multicolumn{5}{c}{ Treatment } \\
Variable & Control & Corn oil & $\begin{array}{c}\text { Corn oil + palm } \\
\text { kernel oil }\end{array}$ & SEM & P-value \\
\cline { 2 - 4 } Kikuyu & 12.2 & 12.1 & 12.3 & 0.258 & 0.3988 \\
Concentrate & 4.2 & 4.2 & 4.2 & & \\
Corn silage & 0.9 & 0.9 & 0.9 & & \\
Oil & 0 & 0.72 & 0.72 & & \\
Total intake & 17.3 & 17.9 & 18.1 & 0.270 & 0.5129 \\
\hline
\end{tabular}

SEM - standard error of the mean. 
The proportion of 12:0, 14:0, and 16:0 FA in milk was higher for $\mathrm{C}$ and $\mathrm{CO}: \mathrm{PKO}$ in relation to $\mathrm{CO}(\mathrm{P}=0.0241$, $\mathrm{P}=0.0044$, and $\mathrm{P}=0.0109$ respectively). For $14: 1_{\mathrm{t}}$ and $16: 1_{t 9}$, the previous treatment (carryover effects) affected the response of the treatment. The addition of oils increased milk proportions in 18:0, 18:1 $1_{\mathrm{c} 9}, 18: 1_{\mathrm{t} 11}$, and $18: 2_{\mathrm{c} 9 \mathrm{t} 11}$ CLA FA in relation to $\mathrm{C}$, but these acids were greater for $\mathrm{CO}(\mathrm{P}=0.0005, \mathrm{P}=0.0188, \mathrm{P}=0.0145$, and $\mathrm{P}<0.0001$, respectively). The addition of oils increased the level of monounsaturated $(\mathrm{P}=0.0138)$, polyunsaturated $(\mathrm{P}=0.0027)$, and preformed $(\geq 18 \mathrm{C})$ ( $\mathrm{P}=0.0063)$ FA in milk, but decreased the thrombogenicity and atherogenicity indexes $(\mathrm{P}=0.0056$ and $\mathrm{P}=0.0085)$ (Table 8$)$.

\section{Discussion}

In our work, concentrate and total intakes were similar among treatments, and the only difference in total intake was explained by oil intake (Table 4). Therefore, differences in the response variables such as milk yield and composition and milk FA profile can be attributed to the addition or non-addition of oil and its FA composition. The main differences in nutrient intake (such as energy) were the result of oil supplementation, although other reports suggest that fat supplementation can lower dry matter voluntary intake (Palmquist, 1984; Gagliostro and Chilliard, 1992; Schröeder et al., 2004). Energy supplementation through the use of fats and oils has been widely documented in total mixed ration (TMR) systems. In these systems, most of authors report a decrease in voluntary feed intake even with the use of protected fats (Palmquist, 1984; Gagliostro and Chilliard, 1992; Schröeder et al., 2004). These negative effects are higher when dietary fat concentration exceeds 80-90 $\mathrm{g} \mathrm{kg}^{-1}$ (Palmquist and Jenkins, 1980), also with the incremental proportion of unsaturated FA of the supplemented lipids (Firkins and Eastridge, 1994;

Table 5 - Effect of supplementing $\left(720 \mathrm{~g} \mathrm{~d}^{-1}\right)$ corn oil or its mixture with palm kernel oil $(75: 25)$ to grazing dairy cows on diet digestibility and rumen fermentation parameters

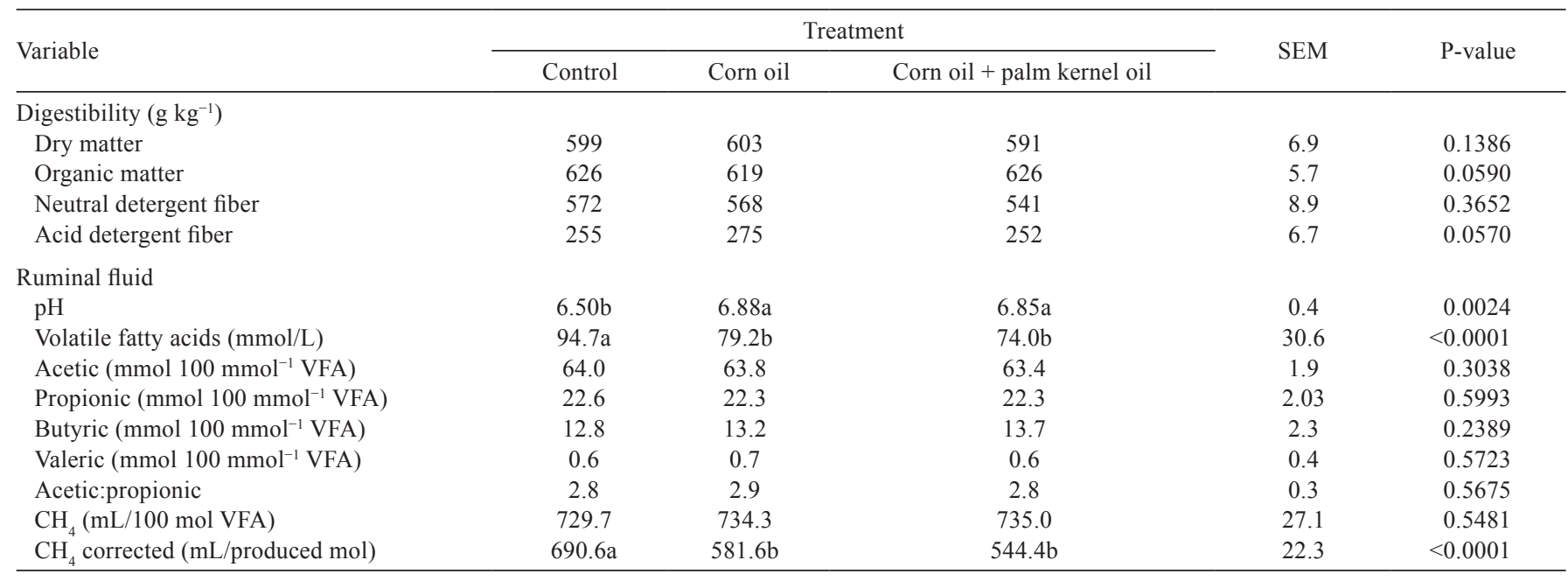

Values followed by the same letter within rows are not significantly different $(\mathrm{P}=0.05)$.

SEM - standard error of the mean; VFA - volatile fatty acid.

Table 6 - Milk yield and composition of milk from grazing cows supplemented with $720 \mathrm{~g} \mathrm{~d}^{-1}$ of corn oil or its mixture with palm kernel oil $(75: 25)$, or unsupplemented (control)

\begin{tabular}{|c|c|c|c|c|c|}
\hline \multirow{2}{*}{ Variable } & \multicolumn{3}{|c|}{ Treatment } & \multirow{2}{*}{ SEM } & \multirow{2}{*}{ P-value } \\
\hline & Control & Corn oil & Corn oil + palm kernel oil & & \\
\hline \multicolumn{6}{|l|}{ Yield $\left(\mathrm{kg} \mathrm{d}^{-1}\right)$} \\
\hline Milk & $21.4 \mathrm{~b}$ & $23.6 \mathrm{a}$ & $23.9 \mathrm{a}$ & 0.326 & 0.0046 \\
\hline Energy-corrected milk & $19.5 b$ & $23.2 \mathrm{a}$ & $23.5 \mathrm{a}$ & 0.480 & 0.0021 \\
\hline Total solids & $2.31 b$ & $2.78 \mathrm{a}$ & $2.76 \mathrm{a}$ & 0.061 & 0.0320 \\
\hline Protein & 0.66 & 0.75 & 0.74 & 0.022 & 0.0566 \\
\hline Fat & $0.67 \mathrm{~b}$ & $0.81 \mathrm{a}$ & $0.82 \mathrm{a}$ & 0.017 & 0.0184 \\
\hline \multicolumn{6}{|l|}{ Concentration (g kg milk $\left.{ }^{-1}\right)$} \\
\hline Total solids & $108 b$ & $118 \mathrm{a}$ & $116 \mathrm{a}$ & 1.48 & 0.0320 \\
\hline Protein & 30.7 & 31.9 & 31.1 & 0.25 & 0.0566 \\
\hline Fat & $31.5 b$ & $34.0 \mathrm{a}$ & $34.3 \mathrm{a}$ & 0.38 & 0.0184 \\
\hline
\end{tabular}

Values followed by the same letter within rows are not significantly different $(\mathrm{P}=0.05)$.

SEM - standard error of the mean. 
Bremmer et al., 1998). However, Ueda et al. (2003), Zheng et al. (2005), Dai et al. (2011), and Benchaar et al. (2012) found no effect on dry matter intake with the addition of different sources and levels of lipids in TMR systems. In their review on fat supplementation to grazing dairy cattle, Schroeder et al. (2004) and Bargo et al. (2003) found no effect of supplementation with lipids on dry matter intake in grazing dairy cattle.

Several authors have suggested that grazing limits voluntary intake and milk production in dairy cattle (Kolver and Muller, 1998; Bargo et al., 2002; Rego et al., 2016). Therefore, it is possible that under grazing conditions there

Table 7 - Milk fatty acid composition ( $\mathrm{g} 100 \mathrm{~g}$ fatty acids ${ }^{-1}$ ) of grazing cows supplemented with $720 \mathrm{~g} \mathrm{~d}^{-1}$ of corn oil or its mixture with palm kernel oil (75:25) or unsupplemented (control)

\begin{tabular}{|c|c|c|c|c|c|}
\hline \multirow{2}{*}{ Fatty acid } & \multicolumn{3}{|c|}{ Treatment } & \multirow{2}{*}{ SEM } & \multirow{2}{*}{ P-value } \\
\hline & Control & Corn oil & Corn oil + palm kernel oil & & \\
\hline $4: 0$ & 2.31 & 2.44 & 2.54 & 0.058 & 0.4013 \\
\hline $6: 0$ & 1.93 & 1.64 & 1.76 & 0.044 & 0.2106 \\
\hline 8:0 & $1.24 \mathrm{a}$ & $0.95 b$ & $1.03 \mathrm{~b}$ & 0.043 & $<0.0001$ \\
\hline 10:0 & $3.00 \mathrm{a}$ & $2.07 \mathrm{~b}$ & $2.26 \mathrm{~b}$ & 0.130 & 0.0061 \\
\hline 11:0 & $0.40 \mathrm{a}$ & $0.23 b$ & $0.28 b$ & 0.026 & 0.0476 \\
\hline 12:0 & $3.74 \mathrm{a}$ & $2.48 \mathrm{c}$ & $3.45 b$ & 0.173 & 0.0241 \\
\hline 13:0 & 0.09 & 0.05 & 0.07 & 0.008 & 0.1467 \\
\hline 14:0 & $12.55 \mathrm{a}$ & $9.99 \mathrm{c}$ & $11.28 \mathrm{~b}$ & 0.299 & 0.0044 \\
\hline $14: 1_{t 9}$ & $0.29 \mathrm{a}$ & $0.21 \mathrm{~b}$ & $0.22 \mathrm{~b}$ & 0.010 & 0.0013 \\
\hline $14: 1_{c 9}$ & $0.34 \mathrm{a}$ & $0.28 b$ & $0.27 b$ & 0.011 & 0.0079 \\
\hline $15: 0$ & $1.42 \mathrm{a}$ & $1.06 \mathrm{~b}$ & $1.15 b$ & 0.089 & 0.2230 \\
\hline $15: 1$ & $1.31 \mathrm{a}$ & $0.94 b$ & $0.97 \mathrm{~b}$ & 0.047 & 0.0037 \\
\hline 16:0 & $36.82 \mathrm{a}$ & $27.55 b$ & $30.97 \mathrm{~b}$ & 1.046 & 0.0109 \\
\hline $16: 1_{t 9}$ & $0.27 \mathrm{a}$ & $0.26 \mathrm{a}$ & $0.25 b$ & 0.011 & 0.0302 \\
\hline $16: 1_{c 9}$ & 1.66 & 1.16 & 1.30 & 0.079 & 0.4455 \\
\hline $17: 0$ & 0.33 & 0.21 & 0.20 & 0.021 & 0.3955 \\
\hline $17: 1 c 9$ & $0.81 \mathrm{a}$ & $0.68 \mathrm{~b}$ & $0.58 \mathrm{~b}$ & 0.031 & 0.0374 \\
\hline $18: 0$ & $9.15 b$ & $13.65 \mathrm{a}$ & $12.46 \mathrm{a}$ & 0.585 & 0.0448 \\
\hline $18: 1_{\mathrm{t} 4}+18: 1_{\mathrm{t} 10}$ & $1.27 \mathrm{c}$ & $3.32 \mathrm{a}$ & $1.93 \mathrm{~b}$ & 0.217 & 0.0005 \\
\hline $18: 1_{c 9}$ & $17.50 \mathrm{~b}$ & $25.63 \mathrm{a}$ & $23.11 \mathrm{a}$ & 1.007 & 0.0188 \\
\hline $18: 1_{\mathrm{t} 11}$ & $0.74 \mathrm{~b}$ & $1.86 \mathrm{a}$ & $1.14 \mathrm{ab}$ & 0.103 & 0.0145 \\
\hline $18: 2{ }_{\mathrm{c} 9 \mathrm{c} 12}$ & 0.81 & 1.12 & 1.04 & 0.047 & 0.0917 \\
\hline $18: 3_{\mathrm{c} 9 \mathrm{c} 12 \mathrm{c} 15}$ & 0.32 & 0.26 & 0.23 & 0.012 & 0.0625 \\
\hline $18: 2_{c 9 t 11}$ CLA & $0.68 \mathrm{c}$ & $1.56 \mathrm{a}$ & $1.01 \mathrm{~b}$ & 0.045 & $<0.0001$ \\
\hline $18: 2_{\mathrm{t} 10 \mathrm{c} 12}$ CLA & 0.11 & 0.08 & 0.06 & 0.006 & 0.0155 \\
\hline Not identified & 0.90 & 0.60 & 0.42 & 0.043 & 0.1707 \\
\hline
\end{tabular}

Values followed by the same letter within rows are not significantly different $(\mathrm{P}=0.05)$.

SEM - standard error of the mean.

Table 8 - Fatty acid composition of milk (g $100 \mathrm{~g}^{-1}$ fatty acids) from grazing cows supplemented with corn oil or its mixture with palm kernel oil (75:25)

\begin{tabular}{|c|c|c|c|c|c|}
\hline \multirow{2}{*}{ Variable } & \multicolumn{3}{|c|}{ Treatment } & \multirow{2}{*}{ SEM } & \multirow{2}{*}{ P-value } \\
\hline & Control & Corn oil & Corn oil + palm kernel oil & & \\
\hline Saturated & $72.99 \mathrm{a}$ & $62.32 \mathrm{c}$ & $67.45 b$ & 1.172 & 0.0141 \\
\hline Unsaturated & $26.11 \mathrm{c}$ & $37.08 \mathrm{a}$ & $31.92 b$ & 1.202 & 0.0107 \\
\hline Monounsaturated & $24.19 \mathrm{c}$ & $34.04 \mathrm{a}$ & $29.58 b$ & 1.092 & 0.0138 \\
\hline Polyunsaturated & $1.92 \mathrm{c}$ & $3.03 \mathrm{a}$ & $2.34 \mathrm{~b}$ & 0.125 & 0.0027 \\
\hline Odd chain & 4.36 & 3.18 & 3.25 & 0.177 & 0.0705 \\
\hline De novo $(\leq 17 \mathrm{C})$ & $68.51 \mathrm{a}$ & $52.22 \mathrm{c}$ & $58.58 \mathrm{~b}$ & 1.742 & 0.0065 \\
\hline Preformed $(\geq 18 C)$ & $30.59 \mathrm{c}$ & $47.18 \mathrm{a}$ & $40.79 b$ & 1.778 & 0.0063 \\
\hline Saturated:unsaturated & $2.81 \mathrm{a}$ & $1.69 b$ & $2.13 b$ & 0.127 & 0.0083 \\
\hline$\omega 3 / \omega 6$ & $0.35 \mathrm{a}$ & $0.22 b$ & $0.21 \mathrm{~b}$ & 0.024 & 0.0498 \\
\hline Atherogenicity index & $2.05 \mathrm{a}$ & $1.08 \mathrm{~b}$ & $1.44 b$ & 0.106 & 0.0056 \\
\hline Thrombogenicity index & $3.87 \mathrm{a}$ & $2.16 b$ & $2.84 b$ & 0.186 & 0.0085 \\
\hline
\end{tabular}

Values followed by the same letter within rows are not significantly different $(\mathrm{P}=0.05)$.

SEM - standard error of the mean. 
is not a feedback to reduce intake when the energy density of the diet increases by the addition of fats, since the cow is under a negative energy balance (Pérez-Prieto et al., 2013).

Lipids have different mechanisms to alter rumen fermentation and reduce $\mathrm{CH}_{4}$ production. Among them are the reduction of diet digestibility (Beauchemin et al., 2008; Martin et al., 2010), changes in the rumen fermentation routes (Yabuuchi et al., 2006), toxic effects on ruminal microorganisms (Patra, 2013; Patra, 2014), biohydrogenation (BH) of unsaturated FA (Martin et al., 2010), decrease in voluntary feed intake, and change in the proportion of fermentable carbohydrates, such as the substitution of fermentable energy by lipids (McGinn et al., 2004; Martin et al., 2010).

Although in our work $\mathrm{CH}_{4}$ production was not measured directly, it was estimated using final fermentation products (Ramin and Huhtanen, 2012). Inclusions of $40 \mathrm{~g} \mathrm{~kg}^{-1}$ of oils in diet decreased estimated $\mathrm{CH}_{4}$ production by almost $16 \%$ (Table 5). Giger-Riverdin et al. (2003), Eugene et al. (2008), and Beauchemin et al. (2008) reported that $\mathrm{CH}_{4}$ production is reduced between $2.2 \%$ and $5 \%$ per unit of supplemented lipid. Patra (2013) and Patra (2014), in a meta-analysis reported linear decreases close to $4.3 \%$ of total production of $\mathrm{CH}_{4}$ per unit of lipid supplemented in cattle and sheep. In our case, estimated $\mathrm{CH}_{4}$ production was reduced by about $4 \%$ per unit of added oil.

Several authors reported that the addition of oils to ruminant diets reduces the acetic:propionic acid ratio as a result of a lower ruminal degradation of fiber (Machmüller et al., 2000; Beauchemin et al., 2008; Patra, 2014), therefore reducing $\mathrm{CH}_{4}$ production. In our study, the molar proportion of each VFA did not change due to the addition of oils, but their molar concentration was reduced (Table 5). Several authors have reported that addition of oils to ruminant diets reduces the proportion of VFA (Machmüller, 2006) and increases $\mathrm{pH}$ (Ueda et al., 2003) due to a reduction in rumen fermentation as was observed here (Table 5). Unfortunately, rumen digestibility was not measured in our study, but apparent digestibility of DM, OM, NDF, and ADF of total gastrointestinal tract were not different due to the addition of oils as has been reported by several authors (Bateman and Jenkins, 1998; Ueda et al., 2003). It has been suggested that that a lower ruminal digestibility as a result of the use of oils in ruminant diets can be compensated by a higher digestibility in the lower tract (Suttton et al., 1983; Faichney et al., 2002).

The net effect of carbohydrate digestion site (rumen vs. lower tract) on the $\mathrm{CH}_{4}$ yield per animal cannot be predicted. However, if the addition of lipids decreases starch and fiber ruminal fermentation and this is compensated by enzymatic digestion in the small intestine (starch) and large intestine fermentation (fiber), these would decrease the production of $\mathrm{CH}_{4}$ as a result of lower total carbohydrates fermentation. The net effect on oil addition may be dependent on the proportion of starch in the diets (Ueda et al., 2003).

In our work, we also compared the effect of FA profile of oils on ruminal fermentation, and in particular, the effects of adding palm kernel oil. The reduction in $\mathrm{CH}_{4}$ production due to the replacement of $25 \%$ of corn oil by palm kernel oil was $5.4 \%$, but was not significant, similarly to that reported by Machmüller et al. (2000) comparing coconut oil (profile similar to palm kernel oil) and sunflower seeds (rich in 18:2 $2_{\mathrm{c} 9 \mathrm{cl} 2}$ as corn oil) added to lamb diets. However, several authors suggest a greater antimethanogenic effect of lipids rich in saturated medium chain FA (12:0 and 14:0 mainly) (Eugene et al., 2008; Beauchemin et al., 2008; Patra, 2014). It is possible that higher concentrations of oils richer in these acids than those used in this study should be used to achieve these effects.

We expected that the addition of oils rich in polyunsaturated FA to the diet of grazing cows increased milk yield and decreased milk fat concentration as has been reported by others (Chilliard et al., 2001; Rabiee et al., 2012). In agreement with these reports, milk yield increased due to the addition of oils and was independent of oil source ( $\mathrm{CO}$ or $\mathrm{CO}: \mathrm{PKO}$ ). Higher milk yield due to dietary addition of oils has been attributed to an increase in energy intake (Van Knegsel et al., 2007; Schröeder et al., 2004). In our study, the oil diets also increased milk fat regardless of the source, resulting in an increase of $19 \%$ in ECM yield. Bargo et al. (2003) and Schröeder et al. (2004) suggest that in restricted grazing animals, milk yield increases in proportion to additional energy intake in the diet without changing milk composition. In our study, the increase in milk fat concentration occurred as a result of an increase in the uptake of preformed FA $\left(205,387,336 \mathrm{~g} \mathrm{~d}^{-1}\right.$ for $\mathrm{C}, \mathrm{CO}$, and $\mathrm{CO}: \mathrm{PKO}$, respectively) by the mammary gland more likely of dietary origin. In a recent review, Loften et al. (2014) reported that increasing the flow of FA 16:0, 18:0, and 18:1 to the duodenum increases milk fat yield and milk fat concentration. We suggest that the increase in milk fat yield and milk fat concentration found in our experiment was due to ruminal biohydrogenation of 18:2 and consequently a larger absorption of 18:0 FA in the duodenum.

Different authors indicate that fat supplementation with a high degree of unsaturation such as those used in our study (>60 g $100 \mathrm{~g}^{-1} \mathrm{FA}$ ) decreases milk fat (Garnsworthy, 1990; Bauman and Griinari, 2001; Chilliard et al., 2001). 
It has been argued that unsaturated FA are precursors in the rumen of particular FA (18:2 ${ }_{\mathrm{t} 10 \mathrm{c} 12}$ CLA and 18:2 $2_{\mathrm{t} 8 \mathrm{c} 10}$ CLA, among others) that inhibit fat synthesis in the mammary gland (Bauman and Griinari, 2001; Baumgard et al., 2002). In this study, milk fat yield $\left(\mathrm{g} \mathrm{d}^{-1}\right)$ from de novo synthesized $\mathrm{FA}$ ( $\leq 17$ carbons) was similar among treatments $(423,459$, $474 \mathrm{~g} \mathrm{~d}^{-1}$ for $\mathrm{C}, \mathrm{CO}$, and $\mathrm{CO}: \mathrm{PKO}$, respectively); thus, this mechanism seems unlikely, according to the higher level of unsaturated FA for the oil treatments compared with control. Several studies suggest that fat supplementation reduces the concentration of milk protein (Zhang et al., 2006) with an increase in its yield $\left(\mathrm{g} \mathrm{d}^{-1}\right)$ due to a greater milk production (Fearon et al., 2004; Flowers et al., 2008). In this study, protein concentrations in milk were similar among the treatments regardless of the addition of oils to the diet. However, daily protein excreted increased due to a greater volume of milk in cows fed diets including oils.

As regards corn oil, this work ought to increase the proportion of unsaturated FA in milk fat, particularly $18: 1_{\text {t11 }}$ TVA and 18:2 ${ }_{c 9 t 11}$ CLA adding an oil rich in 18:2 ${ }_{\mathrm{c} 9 \mathrm{c} 12}$ (corn) to the diet of dairy cows. These FA have been associated with beneficial effects on human health (Druart et al., 2014; El Roz et al., 2013; Yang et al., 2015). The addition of corn oil reduced $(15 \%)$ the saturation of milk fat by increasing 1.42 times the unsaturated FA. The increase was mainly explained by the monounsatured (88\%) FA, particularly oleic acid, which represented $89 \%$ of these. Polyunsaturated FA also increased 1.58 times in milk fat by the addition of corn oil, but these are a small proportion of it. All unhealthy medium chain (Mensink et al., 2003; Nicolosi et al., 1997) saturated FA (12:0, 14:0 and 16:0) were reduced (Table 7). The only saturated FA that increased was stearic acid (18:0). The proportion of 18: $1_{\mathrm{t} 11}$ TVA and 18:2 ${ }_{\mathrm{c} 9 \mathrm{t} 11}$ CLA in milk fat increased at least twice due to addition of corn oil. These FA has been associated with beneficial effects on human health (Rosberg-Cody et al., 2011; Druart et al., 2014; El Roz et al., 2013; Yang et al., 2015).

Several authors have reported that addition of vegetable oils rich in polyunsaturated FA (18:2 ${ }_{c 9 c 12}$ and $\left.18: 2_{c 9 c 12 c 15}\right)$ increases the proportions of unsaturated FA and 18:2 ${ }_{c 9 t 11} \mathrm{CLA}$ in milk fat (Dhiman et al., 2000; Harvatine and Bauman, 2006) as was observed in our study. In conditions similar to those in this study, we found similar proportions of $18: 2_{\mathrm{c} 9} \mathrm{t11}$

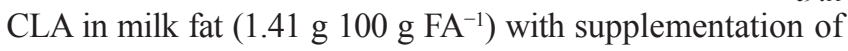
high-fat rice bran (Castaño et al., 2014).

In laboratory research with animals, a preventive intake of $0.8 \mathrm{~g} \mathrm{day}^{-1}$ of 18:2 ${ }_{\mathrm{c} 9 \mathrm{t} 11}$ CLA has been suggested against tumors (Watkins and Li, 2003). On the other hand, the health effects of 18:2 ${ }_{c 9}$ t11 CLA intake on atherosclerosis may be close to $0.25 \mathrm{~g} \mathrm{day}^{-1}$ (calculation by extrapolation of effects observed in experiments with laboratory animals to human metabolic weight). We found levels of $18: 2_{\mathrm{c} 9 t 11}$ CLA in milk of $1.56 \mathrm{mg} \mathrm{g}^{-1}$ milk fat, which are insufficient to achieve the recommended intake for preventive effects on tumors assuming an average Colombian milk consumption of $0.45 \mathrm{~kg} \mathrm{~d}^{-1}$ (IDF, 2013). However, these levels are enough for the prevention of formation of atheromas.

In our work, milk fat with lower indexes of atherogenicity and thrombogenicity resulted from a diet with addition of corn oil, due to a lower proportion of saturated FA (12:0, 14:0, 16:0, and 18:0) and a higher proportion of unsaturated fatty acids. These indexes have been associated with human health (Lock and Bauman, 2004; Fontecha et al., 2009 ) and were reduced by more than $50 \%$, suggesting that the inclusion of corn oil to grazing dairy cows is a valid strategy to decrease the risk of atheromas and thrombus in humans associated with milk fat intake.

Partial substitution of corn oil by palm kernel oil (75:25): in our experiment, palm kernel oil was added to corn oil to reduce $\mathrm{CH}_{4}$ production. The small proportion of palm oil added to corn oil reduced the proportions of $18: 1_{c 9}, 18: 1_{\mathrm{t} 11}$ TVA, and 18:2 ${ }_{\mathrm{c} 9 \mathrm{t} 11}$ CLA, and 12:0, 14:0, and 16:0, were increased. These resulted in an increase of saturation $(8.0 \%)$ and reduced the unsaturation (14\%) of FA in milk fat. However, there was not a significant change in the atherogenicity and thrombogenicity indexes (Table 8) compared with corn oil. Several authors report that dairy cow diets that contain coconut oil, with a similar FA profile to that of palm kernel oil, increase the proportion of 12:0, 14:0, and 16:0 in milk, suggesting that the transfer of these FA from the diet to the product is high and their increase is positively related to their inclusion levels (Hermansen, 1995; Hristov et al., 2009). In our study, the low levels of palm kernel oil (180 $\mathrm{g}$ cow d $\left.^{-1}\right)$ explained the small and not significant changes in health indexes. However, the significant increase in medium chain FA in milk fat due to palm kernel oil addition should be considered negative. These FA are related to human health problems, specifically circulatory system diseases (Nicolosi et al., 1997; Mensink et al., 2003).

\section{Conclusions}

The addition of oils to diets of grazing cows is an option to increase milk volume, changing its fatty acid composition and decreasing $\mathrm{CH}_{4}$ production. However, to achieve adequate levels of $18: 1_{t 11}$ and 18:2 ${ }_{\mathrm{c} 9 t 1}$ conjugated linoleic acid (therapeutic and preventive) in milk, oil inclusion in the diet must be increased, with potential effects on animal productivity. 


\section{Acknowledgments}

This study was supported by the Direction of Research Bogotá (DIB) Universidad Nacional de Colombia.

\section{References}

Aguilar, O. X.; Moreno, B. M.; Pabón, M. L. and Carulla, J. E. 2009. Efecto del consumo de kikuyo (Pennisetum clandestinum) o raigrás (Lolium hibridum) sobre la concentración de ácido linoléico conjugado y el perfil de ácidos grasos de la grasa láctea. Livestock Research for Rural Development 21(49).

AOAC - Association Official to Analytical Chemistry. 2010. Official methods of analysis of AOAC International. 18th ed. AOAC International, Gaithersburg, MD.

Bargo, F.; Muller, L. D.; Delahoy, J. E. and Cassidy, T. W. 2002. Performance of high producing dairy cows with three different feeding systems combining pasture and total mixed rations. Journal of Dairy Science 85:2948-2963.

Bargo, F.; Muller, L. D.; Kolver, E. S. and Delahoy, J. E. 2003. Invited review: Production and digestion of supplemented dairy cows on pasture. Journal of Dairy Science 86:1-42.

Bateman, H. G. and Jenkins, J .C. 1998. Influence of soybean oil in high fiber diets fed to nonlactating cows on ruminal unsaturated fatty acids and nutrient digestibility. Journal of Dairy Science 81:2451-2458.

Bauman, D. E. and Griinari, J. M. 2001. Regulation and nutritional manipulation of milk fat: low-fat milk syndrome. Livestock Production Science 70(1-2):15-29.

Baumgard, L. H.; Matitashvili, E.; Corl, B. A.; Dwyer, D. A. and Bauman, D. E. 2002. Trans-10, cis-12 Conjugated linoleic acid decreases lipogenic rates and expression of genes involved in milk lipid synthesis in dairy cows. Journal of Dairy Science 85:2155-2163.

Beauchemin, K. A.; Kreuzer, M.; O'Mara, F. and McAllister, T. A. 2008. Nutritional management for enteric methane abatement: a review. Australian Journal of Experimental Agriculture 48:21-27.

Benchaar, C.; Romero-Pérez, G. A.; Chouinard, P. Y.; Hassanat, F.; Eugene, M.; Petit, H. V. and Côrtes, C. 2012. Supplementation of increasing amounts of linseed oil to dairy cows fed total mixed rations: effects on digestion, ruminal fermentation characteristics, protozoal populations, and milk fatty acid composition. Journal of Dairy Science 95:4578-4590.

Bremmer, D. R.; Ruppert, L. D.; Clark, J. H. and Drackley, J. K. 1998. Effects of chain length and unsaturation of fatty acid mixtures infused into the abomasum of lactating dairy cows. Journal of Dairy Science 81:176-188.

Castaño, G. A.; Pabón, M. L. and Carulla, J. E. 2014. Concentration of trans-vaccenic and rumenic acids in the milk from grazing cows supplemented with palm oil, rice bran or whole cottonseed. Revista Brasileira de Zootecnia 43:315-326.

Castillo, J. A.; Olivera, M.; Pabón, M. L. and Carulla, J. E. 2012. Reducción de la biohidrogenación del ácido linoleico y alfa linolénico por la adición de diferentes proporciones de ácido eicosapentaenoico y docosahexaenoico. Revista Colombiana de Química 41:395-408.

Chilliard, Y.; Ferlay, A. and Doreau, M. 2001. Effect of different types of forages, animal fat or marine oils in cow's diet on milk fat secretion and composition, especially conjugated linoleic acid (CLA) and polyunsaturated fatty acids. Livestock Production Science 70:31-48.

Cook, C. W. 1964. Symposium on nutrition forages and pastures: Collecting forage samples representative of ingested material of grazing animals for nutritional studies. Journal of Animal Science 23:265-270.

Dai, X. J.; Wang, C. and Zhu, Q. 2011. Milk performance of dairy cows supplemented with rapeseed oil, peanut oil and sunflower seed oil. Czech Journal of Animal Science 56:181-191.

Dhiman, T. R.; Satter, L. D.; Pariza, M. W.; Galli, M. P.; Albright, K. and Tolosa M. X. 2000. Conjugated linoleic acid (CLA) content of milk from cows offered diets rich in linoleic and linolenic acid. Journal of Dairy Science 83:1016-1027.

Díaz-González, G.; Gutiérrez, R.; Pérez, N.; Vega, S.; León, S.; González, M.; Prado, G.; Urbán, G.; Ramírez, A. and Pinto, M. 2002. Detección de adulteraciones en la grasa de leche pasteurizada mexicana. Revista de Salud Animal 24:54-59.

Druart, C.; Dewulf, E.; Cani, P.; Neyrinck, A.; Thissen, J. P. and Delzenne, N. 2014. Gut microbial metabolites of polyunsaturated fatty acids correlate with specific fecal bacteria and serum markers of metabolic syndrome in obese women. Lipids 49:397-402.

El Roz, A.; Bard, J. M.; Huvelin, J. M. and Nazih, H. 2013. The anti-proliferative and pro-apoptotic effects of the trans9, trans11 conjugated linoleic acid isomer on MCF-7 breast cancer cells are associated with LXR activation. Prostaglandins, Leukotrienes and Essential Fatty Acids 88:265-272.

Eugene, M.; Masse, D.; Chiquette, J. and Benchaar, C. 2008. Metaanalysis on the effects of lipid supplementation on methane production in lactating dairy cows. Canadian Journal of Animal Science 88:331-334.

Faichney, G. J.; Gordon, G. L. R.; Welch, R. J. and Rintoul, A. J. 2002. Effect of dietary free lipid on anaerobic fungi and digestion in the rumen of sheep. Crop and Pasture Science 53:519-527.

Fearon, A. M.; Mayne, C. S.; Beattie, J. A. M. and Bruce, D. W. 2004. Effect of level of oil inclusion in the diet of dairy cows at pasture on animal performance and milk composition and properties. Journal of Science Food and Agriculture 84:497-504.

Firkins, J. L. and Eastridge, M. L. 1994. Assessment of the effects of iodine value on fatty acid digestibility, feed intake, and milk production. Journal of Dairy Science 77:2357-2366.

Flowers, G.; Ibrahim, S. A. and Abughazaleh, A. A. 2008. Milk fatty acid composition of grazing dairy cows when supplemented with linseed oil. Journal of Dairy Science 91:722-730.

Fontecha, J.; Recio, M. and Pilosof, M. A. 2009. Componentes bioactivos de la grasa láctea. p.251-273. In: Funcionalidad de los componentes lácteos. Juárez, M. and Fontecha, J., eds. CEE Limencop, S.L. España.

Gagliostro, G. A. and Chilliard, Y. 1992. Utilización de lípidos protegidos en la nutrición de vacas lecheras. I. Efectos sobre la producción y la composición de la leche, y sobre la ingestión de materia seca y energía. Revista Argentina de Producción Animal 12:1-15.

Garcés, R. and Mancha, M. 1993. One step lipid extraction and fatty acid methyl esters preparation from fresh plant tissues. Analytical Biochemistry 211:139-143.

Garnsworthy, P. C. 1990. Feeding calcium salts of fatty acids in highstarch or high-fiber compound supplements to lactating cows at grass. Animal Production Science 51:441-447.

Giger-Reverdin, S.; Morand-Fehr, P. and Tran, G. 2003. Literature survey of the influence of dietary fat composition on methane production in dairy cattle. Livestock Production Science 82:73-79.

Grundy, S. M. 1994. Influence of stearic acid on cholesterol metabolism relative to other long-chain fatty acids. American Journal of Clinical Nutrition 60:986S-990S.

Harvatine, K. J. and Bauman, D. E. 2006. SREBP1 and thyroid hormone response spot 14 (S14) are involved in the regulation of bovine mammary lipid synthesis during diet-induced milk fat depression and treatment with CLA. Journal of Nutrition $136: 2468-2474$. 
Hermansen, J. E. 1995. Prediction of milk fatty acid profile in dairy cows fed dietary fat differing in fatty acid composition. Journal of Dairy Science 78:872-879.

Holden, L. A.; Muller, L. D. and Fales, S. L. 1994. Estimation of intake in high producing Holstein cows grazing grass pasture. Journal of Dairy Science 77:2332-2340.

Hristov, A. N.; Vander Pol, M.; Agle, M.; Zaman, S.; Schneider, C.; Ndegwa, P.; Vaddella, V. K.; Johnson, K.; Shingfield, K. J. and Karnati, S. K. R. 2009. Effect of lauric acid and coconut oil on ruminal fermentation, digestion, ammonia losses from manure, and milk fatty acid composition in lactating cows. Journal of Dairy Science 92:5561-5582.

Hurley, W. L.; Warner, G. J. and Grummer, R. R. 1987. Changes in triglyceride fatty acid composition of mammary secretions during involution. Journal of Dairy Science 70:2406-2410.

IDF - International Dairy Federation. 2013. The world dairy situation 2013. p.24-30. Bulletin of the IDF 470. IDF, Brussels, Belgium.

Khanal, R. C. and Olson, K. C. 2004. Factors affecting conjugated linoleic acid (CLA) content in milk, meat and egg. A review. Pakistan Journal of Nutrition 3:82-98.

Kolver, E. S. and Muller, L. D. 1998. Performance and nutrient intake of high producing Holstein cows consuming pasture or a total mixed ration. Journal of Dairy Science 81:1403-1411.

Kromhout, D.; Menotti, A.; Bloemberg, B.; Aravanis, C.; Blackburn, H.; Buzina, R.; Dontas, A. S.; Fidanza, F.; Giampaoli, S.; Jansen, A.; Karvonen, M.; Katan, M.; Nissinen, S.; Nedeljkovic, J.; Pekkanen, M.; Pekkarinen, S.; Punsar, S.; Rasanen, L.; Simic, B. and Toshima, H. 1995. Dietary saturated and trans-fatty acids and cholesterol and 25-year mortality from coronary heart disease: the Seven Countries Study. Preventive Medicine 24:308-315.

Lim, J. N.; Oh, J. J.; Wang, T.; Lee, S. J.; Kim, S.; Kim, Y. J. and Lee, H. G. 2014. Trans-11 18:1 vaccenic acid (TVA) has a direct anticarcinogenic effect on MCF-7 human mammary adenocarcinoma cells. Nutrients 6:627-636.

Lock, A. L. and Bauman, D. E. 2004. Modifying milk fat composition of dairy cows to enhance fatty acids beneficial to human health. Lipids 39:1197-1206.

Loften, J. R.; Linn, J. G.; Drackley, J. K.; Jenkins, J. C.; Soderholm, C. G. and Kertz, A. F. 2014. Invited review: Palmitic and stearic acid metabolism in lactating dairy cows. Journal of Dairy Science 97:1-14.

Lopez, R.; Pulsipher, G. D.; Guerra-Liera, J. E.; Soto-Navarro, S. A.; Balstad, L. A.; Petersen, M. K.; Dhuyvetter, D. V.; Brown, M. S. and Krehbiel, C. R. 2016. Effects of fad and/or methionine hydroxyl analog added to a molasses-urea-based supplement on ruminal and postruminal digestion and duodenal flow of nutrients in beef steers consuming low-quality lovegrass hay. Journal of Animal Science 94:2485-2496.

Machmüller, A.; Ossowski, D. A. and Kreuzer, M. 2000. Comparative evaluation of the effects of coconut oil, oilseeds and crystalline fat on methane release, digestion and energy balance in lambs. Animal Feed Science and Technology 85:41-60.

Machmüller, A.; Soliva, C. R. and Kreuzer, M. 2003. Effect of coconut oil and defaunation treatment on methanogenesis in sheep. Reproduction Nutrition Development 43:41-55.

Machmüller, A. 2006. Medium-chain fatty acids and their potential to reduce methanogenesis in domestic ruminants. Agriculture, Ecosystems and Environment 112:107-114.

Martin, C.; Morgavi, D. P. and Doreau, M. 2010. Methane mitigation in ruminants: from microbe to the farm scale. Animal 4:351-365.

Matsushita, M.; Tazinafo, N.; Padre, R.; Oliveira, C.; Souza, N.; Visentainer, J.; Macedo, F. and Ribas, N. 2007. Fatty acid profile of milk from Saanen goats fed a diet enriched with three vegetable oils. Small Ruminant Research 72:127-143.
McCreary, D. K.; Kossa, W. C.; Ramachandran, S. and Kurtz, R. R. 1978. A novel and rapid method for the preparation of methyl esters for gas chromatography: application to the determination of the fatty acids of edible fats and oils. Journal of Chromatographic Science 16:329-331.

McGinn, S. M.; Beauchemin K. A.; Coates, T. and Colombato, D. 2004. Methane emissions from beef cattle: Effects of monensin, sunflower oil, enzymes, yeast and fumaric acid. Journal of Animal Science 82:3346-3356.

Mensink, R. P.; Zock, P. L.; Kester, A. D. M. and Katan, M. B. 2003. Effects of dietary fatty acids and carbohydrates on the ratio of serum total to HDL cholesterol and on serum lipids and apolipoproteins: a meta-analysis of 60 controlled trials. American Journal of Clinical Nutrition 77:1146-1155.

Montgomery, S. P.; Drouillard, J. S.; Nagaraja, T. G.; Titgemeyer, E. C. and Sindt, J. J. 2008. Effects of supplemental fat source on nutrient digestion and ruminal fermentation in steers. Journal of Animal Science 86:640-650.

NRC - National Research Council. 2001. Nutrient requerimients of dairy cattle. 7th ed. National Academy Press, Washington DC, USA.

Nicolosi, R. J.; Rogers, E. J.; Kritchevsky, D.; Scimeca, J. A. and Huth, P. J. 1997. Dietary conjugate linoleic acid reduces plasma lipoprotein and early aortic atherosclerosis in hypercholestoremic hamster. Artery 22:266-277.

Palmquist, D. L. and Jenkins, T. C. 1980. Fat in lactation rations: Review. Journal of Dairy Science 63:1-14.

Palmquist, D. L. 1984. Use of fats in diets for lactating dairy cow en Fat in Animal Nutrition. p.357-381. Editions Bultersworkts, London, UK.

Patra, A. K. 2013. The effect of dietary fats on methane emissions, and its other effects on digestibility, rumen fermentation and lactation performance in cattle: A meta-analysis. Livestock Science 155:244-254.

Patra, A. K. 2014. A meta-analysis of the effect of dietary fat on enteric methane production, digestibility and rumen fermentation in sheep, and a comparison of these responses between cattle and sheep. Livestock Science 167:97-103.

Patra, A. K. and Yu, Z. 2013. Effects of coconut and fish oils on methane production, fermentation, abundance and diversity of rumen microbial populations in vitro. Journal of Dairy Science 96:1782-1792.

Pérez-Prieto, L. A.; Peyraud, J. L. and Delagarde, R. 2013. ¿Does pre-grazing herbage mass really affect herbage intake and milk production of strip-grazing dairy cows? Grass and Forages Science 68:93-109.

Peterson, S. E.; Rezamand, P.; Williams, W.; Price, W.; Chahine, M. and McGuire, M. A. 2012. Effect of dietary betaine on milk yield and milk composition of mid-lactacion Holstein dairy cows. Journal of Dairy Science 95:6557-6562.

Plascencia, A.; Mendoza, G. D.; Vásquez, C.; and Zinn, R. A. 2003. Relationship between body weight and level of fat supplementation on fatty acid digestion in feedlot cattle. Journal of Animal Science 81:2653-2659.

Priev, A. and Barenholz, Y. 2010. Ultrasonic food quality analyzer based on cylindrical standing waves. p.173-176. In: Proceedings of 20th International Congress on Acoustics. Sydney, Australia.

Rabiee, A. R.; Breinhild, K.; Scott, W.; Golder, H. M.; Block, E. and Lean, I. J. 2012. Effect of fat additions to diets of dairy cattle on milk production and components: A meta-analysis and metaregression. Journal of Dairy Science 95:3225-3247.

Ramin, M. and Huhtanen, P. 2012. Development of an in vitro method for determination of methane production kinetics using a fully automated in vitro gas system - A modelling approach. Animal Feed Science and Technology 174:190-200. 
Rego, O. A.; Cabrita, A. R.; Rosa, H. J.; Alves, S. P.; Duarte, V.; Fonseca, A. J.; Vouzela, F. M.; Pires, F. R. and Bessa, R. J. 2016. Changes in milk production and milk fatty acid composition of cows switched from pasture to a total mixed ration diet and back to pasture. Italian Journal of Animal Science 15:76-86.

Rosberg-Cody, E.; Stanton, C.; O’Mahony, L.; Wall, R.; Shanahan, F.; Quigley, E. M.; Fitzgerald, G. F. and Ross, R. P. 2011. Recombinant lactobacilli expressing linoleic acid isomerase can modulate the fatty acid composition of host adipose tissue in mice. Microbiology 157:609-615.

Schröeder, G. F.; Gagliostro, G. A.; Bargo, F.; Delahoy, J. E. and Muller, L. D. 2004. Effects of fat supplementation on milk production and composition by dairy cows on pasture: a review. Livestock Production Science 86:1-18.

Storry, J. E.; Hall, A. J. and Johnson, V. W. 1971. The effects of increasing amounts of dietary coconut oil on milk-fat secretion in the cow. Journal of Dairy Research 38:73-77.

Sunvold, G. D. and Cochran, R. C. 1991. Technical note: evaluation of acid detergent lignin, alkaline peroxide lignin, acid insoluble ash, and indigestible acid detergent fiber as internal markers for prediction of alfalfa, bromegrass, and prairie hay digestibility by beef steers. Journal of Animal Science 69:4951-4955.

Sutton, J. D.; Knight, R.; McAllan, A. B. and Smith, R. H. 1983. Digestion and synthesis in the rumen of sheep given diets supplemented with free and protected oils. British Journal of Nutrition 49:419-432.

Ueda, K.; Ferlay, A.; Chabrot, J.; Loor, J. J.; Chilliard, Y. and Doreau, M. 2003. Effect of linseed oil supplementation on ruminal digestion in dairy cows fed diets with different forage:concentrate ratios. Journal of Animal Science 86:3999-4007.

Ulbricht, T. L. V. and Southgate, D. A. T. 1991. Coronary heart disease: seven dietary factors. The Lancet 338:985-992.

Van Knegsel, A. T. M.; Van Den Brand, H.; Dijkstra, J.; Van Straalen, W. M.; Heetkamp, M. J. W.; Tamminga, S. and Kemp, B. 2007.
Dietary energy source in dairy cows in early lactation: energy partitioning and milk composition. Journal of Dairy Science 90:1467-1476

Van Soest, P. J.; Robertson, J. B. and Lewis, B. A. 1991. Methods for dietary fiber, neutral detergent fiber, and nonstarch polysaccharides in relation to Animal nutrition. Journal of Dairy Science 74:3583-3597.

Watkins, B. A. and Li, Y. 2003. CLA in functional food: enrichment of animal products. p.174-188. In: Advances in conjugated linoleic acid research. Sebedio, J. L.; Christie, W. W. and Adolf, R., eds. v.2. AOAC Press, Champaign, Illinois, USA.

Yabuuchi, Y.; Matsushita, Y.; Otsuka, H.; Fukamachi, K. and Kobayashi, Y. 2006. Effects of supplemental lauric acid-rich oils in high-grain diet on in vitro rumen fermentation. Animal Science Journal 77:300-307.

Yamasaki, M.; Kishihara, K.; Ikeda, I.; Sugano, M. and Yamada, K. 1999. A recomended esterification method for gas chromatographic measurement of conjugated linoleic acid. Journal of the American Oil Chemists' Society 76:933-938.

Yang, B.; Chen, H.; Stanton, C.; Ross, R. P.; Zhang, H.; Chen, Y. Q. and Chen, W. 2015. Review of the roles of conjugated linoleic acid in health and disease. Journal of Functional Foods 15:314-325.

Zhang, R. H.; Mustafa, A. F. and Zhao, X. 2006. Effects of feeding oilseed rich in linoleic and linolenic fatty acids to lactating ewes on cheese yield and on fatty acid composition of milk and cheese. Animal Feed Science and Technology 127:220-233.

Zheng, H. C.; Liu, J. X.; Yao, J. H.; Yuan, Q.; Ye, H. W.; Ye, J. A. and $\mathrm{Wu}, \mathrm{Y}$. M. 2005. Effects of dietary sources of vegetable oils on performance of high-yielding lactating cows and conjugated linoleic acids in milk. Journal of Dairy Science 88:2037-2042.

Zinn, R. A.; Gulati, S. K.; Plascencia, A. and Salinas, J. 2000. Influence of ruminal biohydrogenation on the feeding value of fat in finishing diets for feedlot cattle. Journal of Animal Science 78:1738-1746. 